\title{
$\mathrm{X}$ 線透視撮影台の故障分析プログラムの開発
}

\author{
諸澄邦彦 - 渡辺雅弘**佐藤伸雄 ${ }^{* *}$ \\ 松 谷 一 雄*** \\ 埼玉県衛生部循環器病センター準備室 \\ *立正佼成会附属佼成病院 \\ **癌研究会附属病院 \\ ***東邦大学医学部附属大橋病院 \\ （論文受理１992年1月 9日） \\ （最終論文受理１992年 9 月18日） \\ (Code No. 132, 492.2)
}

Key words: Fault Analysis, Fault Tree Analysis, Quality Control, Quality Assurance, Radiographic / Fluoroscopic Table

\section{DEVELOPMENT OF MACHINE FAULT ANALYSIS PROGRAM FOR RADIOGRAPHIC / FLUOROSCOPIC TABLES}

\author{
Kunihiko Morozumi, Masahiro Wtanabe*, Nobuo Sato** \\ Kazuo Matsutani***
}

Project Office for Cardiovascular Center, Saitama Prefectual Government

*Dept. of Radiology, Kohsei General Hospital

**Dept. of Radiology, Cancer Institute Hospital

${ }^{* * *}$ Dept. of Radiology, Toho University Hospital

(Article received: Jan. 9, 1992)

\section{Summary}

The machine fault analysis program was fed into a notebook-type personal computer using the method of fault tree analysis method. It is able to isolate any trouble spots and promptly indicates countermeasures necessary at the equipment site. The key features of this program are as follows:

1) Using a handy personal computer, a decision can be promptly made on the spot as to whether the 
trouble can be repaired by RT or if a service man must be called in.

2) By referring to the program record of the service history, earlier measures taken by a service representative can be followed by the Radiological Technologists, if feasible.

3) By isolating the trouble spot before a service call, necessary parts can be arranged in advance, greatly to reducing the downtime.

4) By referring to the service history, parts likely to cause trouble can be checked beforehand for preventative maintenance.

5) This simulation program helps train new RTs on proper procedures in the event of equipment breakdown.

\section{1. 緒言}

現在の医療に扔いてX線画像情報は欠くことのできな いものとして著しい発展を遂げている，なかでも，X線 透視撮影台はほとんどの病院に設置されており，胃のス クリーニング検查を始めとして消化管検查に非常に有効 な手段として広く利用されている.

日常㟝療業務に扔ける使用頻度が高いということから 考元れば, 機器の品質管理としての保守管理を充分に行 うことによって，故障や事故の発生確率を少なくするこ とが必要である。管理の定義については，「機器の性能維 持, 機械的・電気的安全保持, 放射線被曝に対卞る安全 性の保持をはかるべく保守点検を行うことにより不測の 事故の防止，安定した医療情報の提供および放射線診療 の円滑な運営をはかることにある1).」

しかしながら，経年変化などによって，装置の性能が 低下し，最悪の場合には故障や事故につながることが考 えられる，造影剂を使用した検查中に装置が故障した場 合，迅速な対応をしなければ，被検者の苦痛を伴うばか りでなく，再検査あるいはその後に予定している患者の 再予約など影響は計りしれない，それゆえ，日常の放射 線診療に携わる放射線技師は，据え付け時の性能をどの 程度保持しているかを点検し，必要であれば部品などを 交換して, 故障の防止などの予防保全に努める必要があ $る^{22}$.

放射線機器が故障した場合の対応は，技師の経験とそ の装置に対する知識に左右されるが，現場で修理が可能 な故障かメーカーの技術者をコールする必要があるかを 迅速汇判断するための簡潔, 明膫なマニュアルを作成し ている施設も多い3). そのような故障分析を行うマニュ アル作成の場合, 故障状況による分類をし，故障原因が 追及できるものでなければならないのは言うまでもない， 今回我々は，品質管理プログラムの一環として，パーソ ナルコンピュータ（以下パソコンと略記）による「X線
透視撮影台の故障分析プログラム」を開発したので報告 する。

\section{2. 方 法}

現在使用されている各社のX線透視撮影台はオーバー テーブルチューブ及びアンダーテーブルチューブの分類 以外に同一メーカーでもその機構に大きな違いがある. そこで今回は，東芝製のオーバーテーブルチューブの装 置（DTW-300A）についての故障現象・原因を過去の故 障記録をもとに，好発する現象及び現場修理が可能なも のを中心に分析した.

現象は同じでも原因が異なったり，技師が最初に気づ く現象が異なっても原因が同じ故障もあるので，修理記 録より故障現象を分類した。つぎに故障現象のうち，現 場の技師が携われる修理内容と，メーカーの技術者をコ 一ルする必要がある修理内容に分類した。故障するとす ぐメーカーに電話するのではなく, 現場で修理が可能か 否かの判断をし，ある程度の故障箇所を遡及するためで ある。

現象から故障箇所を判断し，故障原因を追及し，修理 に要する時間までも把握できるフローチャートを一連の 流れでプログラム化した。使用した装置は，NEC 98 NOTE-SX で，プログラム言語として BASIC (86) を用 いた

\section{3. 結果}

プログラムはタイトル画面 (Fig. 1)，メーカー選択画 面 (Fig. 2)，機種選択画面（Fig. 3) の手順で進み，マス ターメニュー画面（Fig.4）で故障現象を選択するよう に，故障に対して即応性のあるシステムの開発に努めた。

1 例として「X線がでない」という現象の場合には，

Fig. 5 から Fig. 8 までのフローチャートに従い, 質問項 目に答えながら進み，故障原因に辿りつく．また，その 故障が現場で修理が可能か否かの判断ができる. 


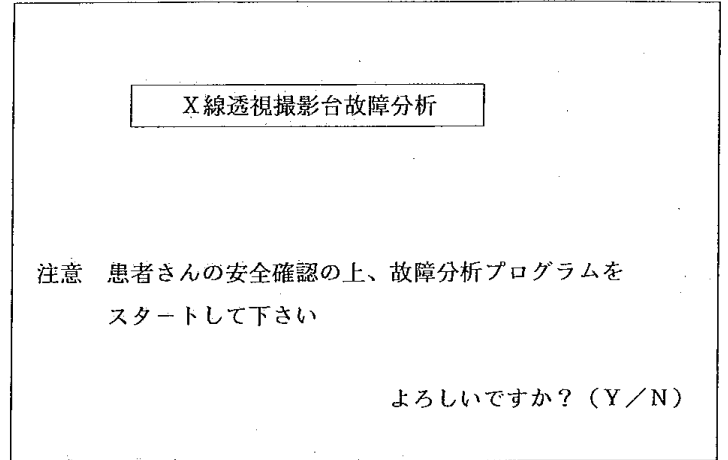

Fig. 1 Display of program title

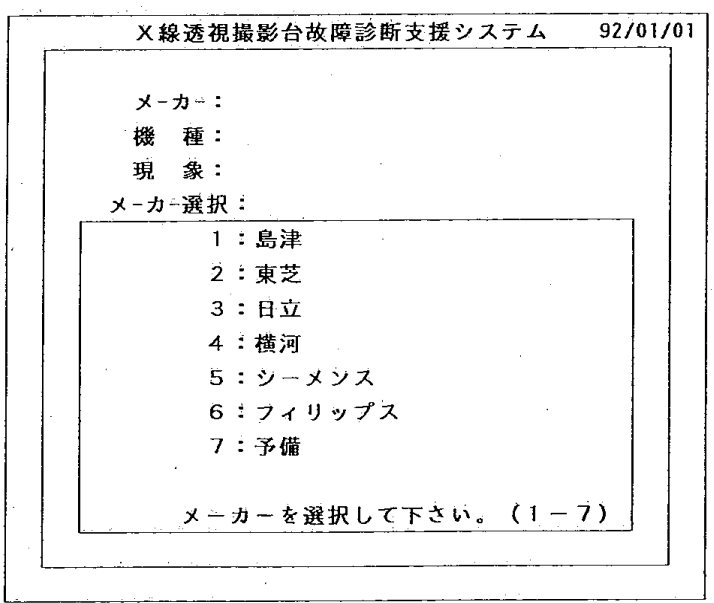

Fig. 2 Display for selection of manufacturer

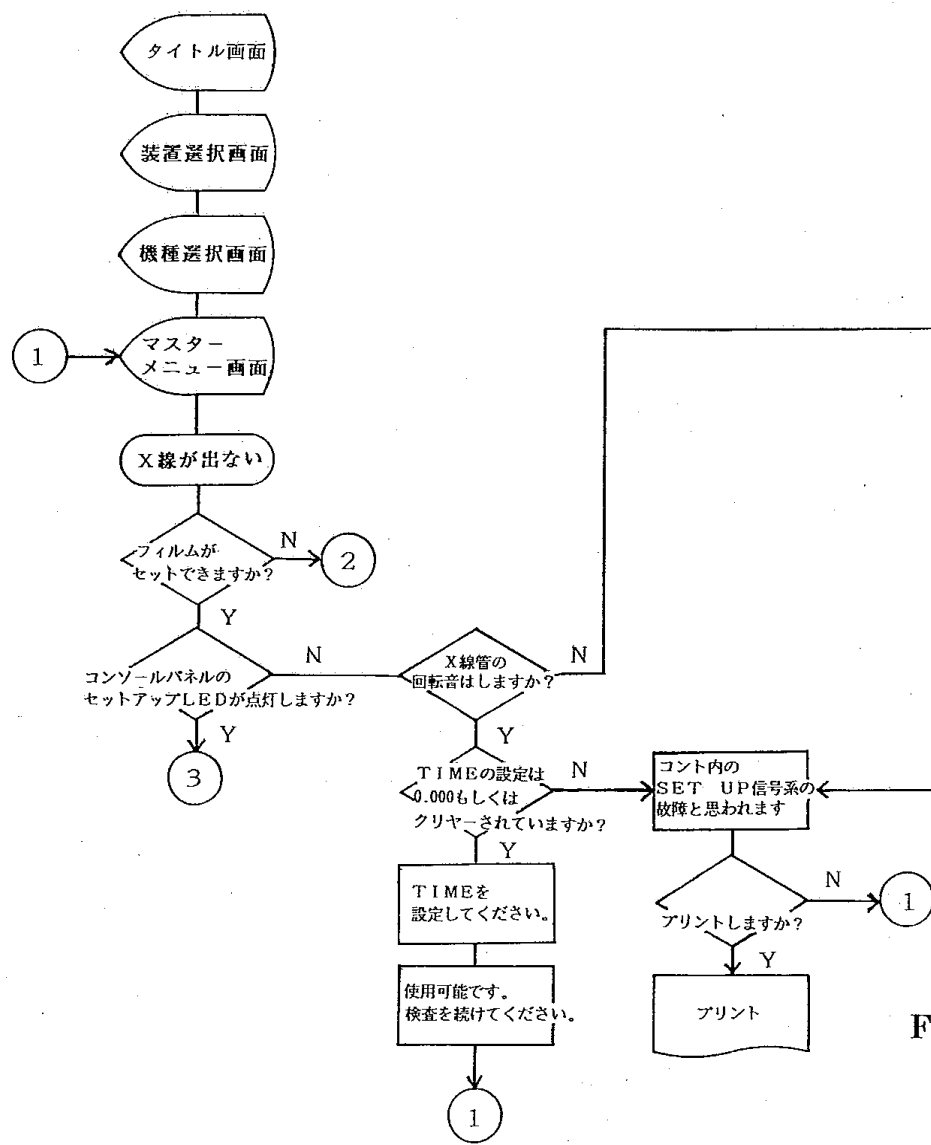

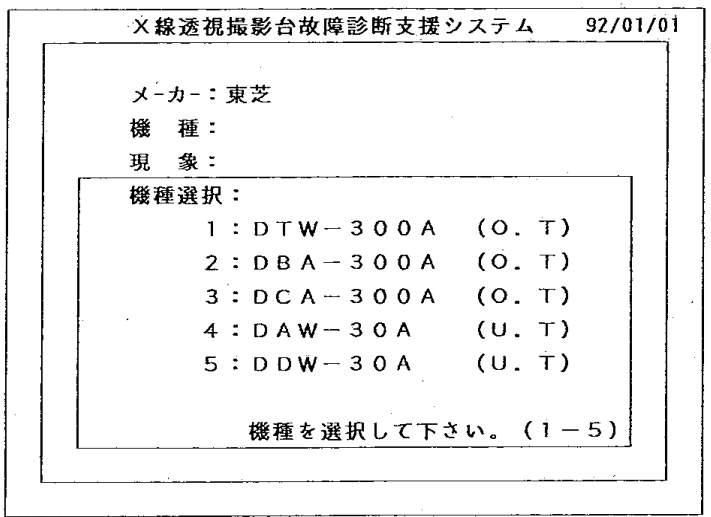

Fig. 3 Display for selection of machine type

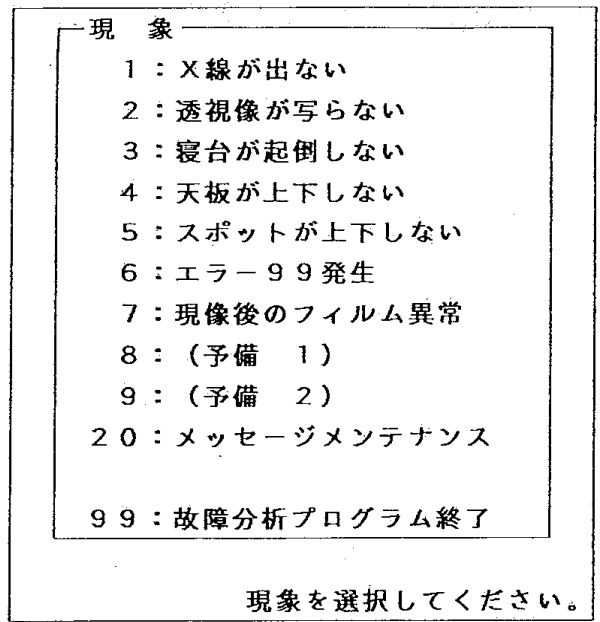

Fig. 4 Display of master menu 


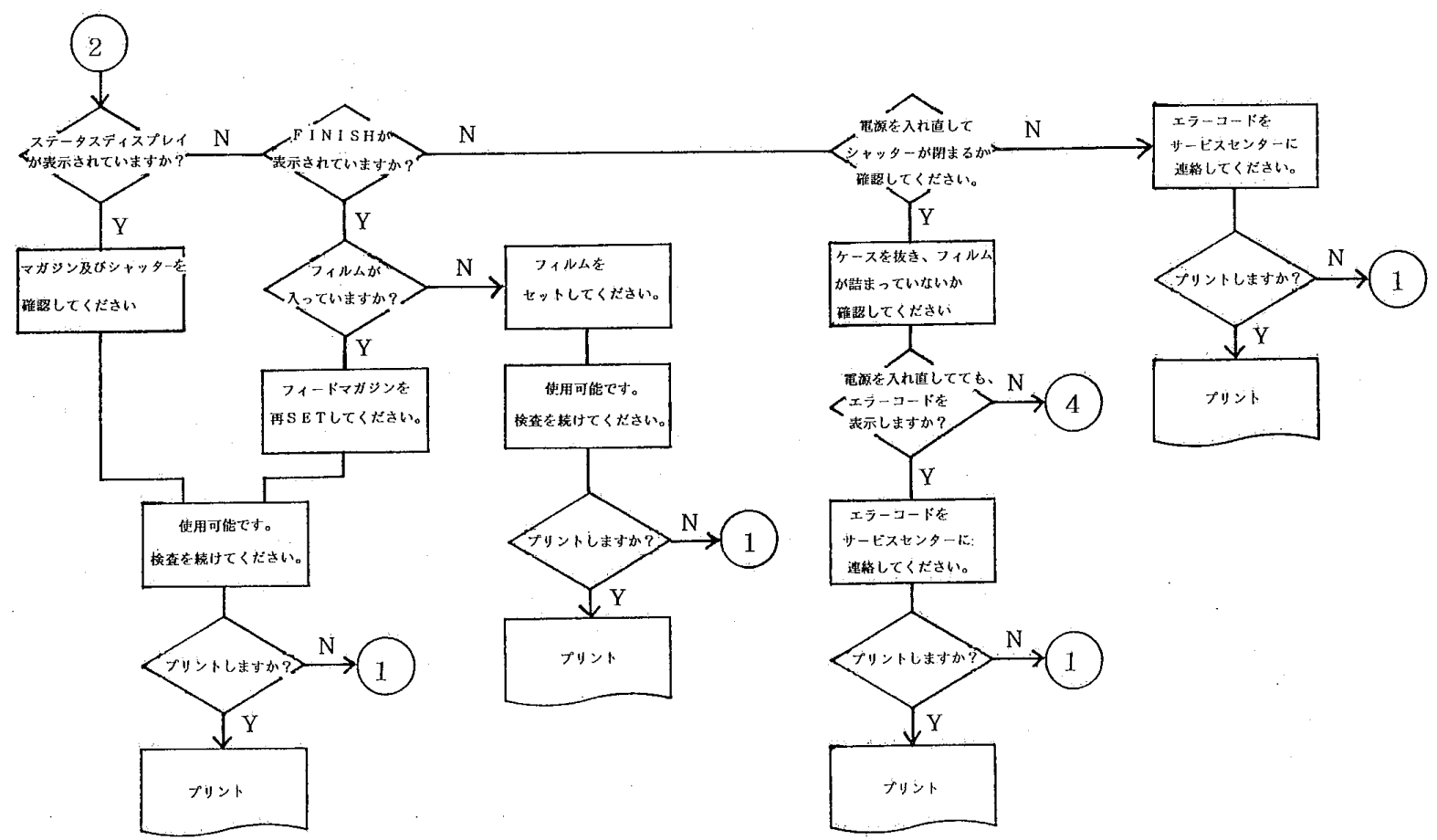

Fig. 6 Flowchart for machine fault analysis program of radiographic/fluoroscopic table---decision point 1-2

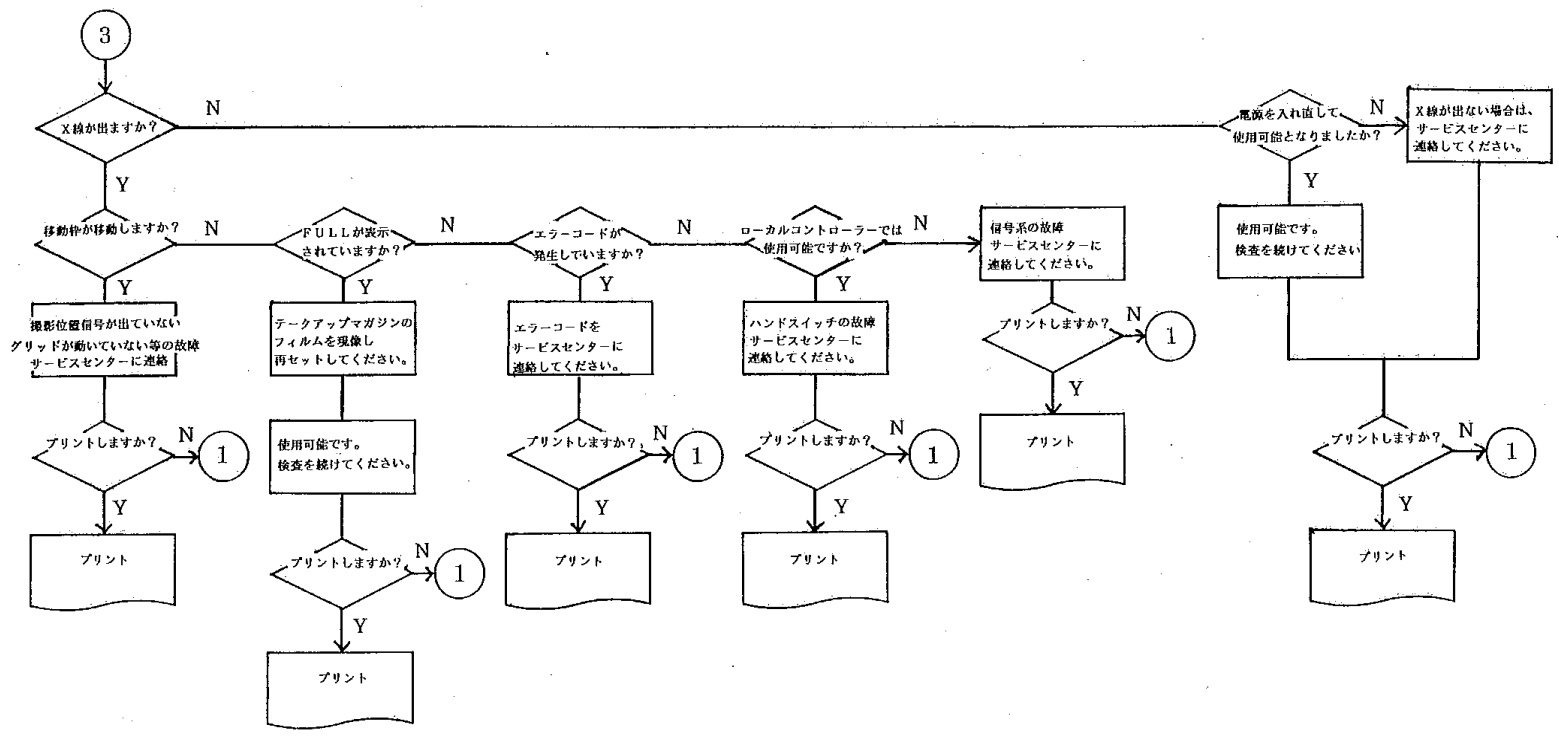

Fig. 7 Flowchart for machine fault analysis program of radiographic/fluoroscopic table---decision point 1-3

ノートタイプのパソコンをX透視撮影台のそばで操作 することにより，故障原因の把握と対策が明確になり， ダウンタイムの減少につながる。

またFig. 9 に示したメッセージメンテナンス画面よ り，各メッセージの追加，登録，変更が可能となってい るので，各施設の機種に合わせることができる。ささらに 本プログラムは，初歩的な BASIC 言語で作られている
ので，各施設に設置されている各メーカーの装置の故障 分析プログラムの開発は可能である.（Fig. 10)

開発したプログラムを埼玉県立寄居こども病院で 2 カ 月間使用した結果，故障時の対策というより，故障が発 生した時を想定したシュミレーションとして，新人技師 の教育的な使用方法で効果があった。 


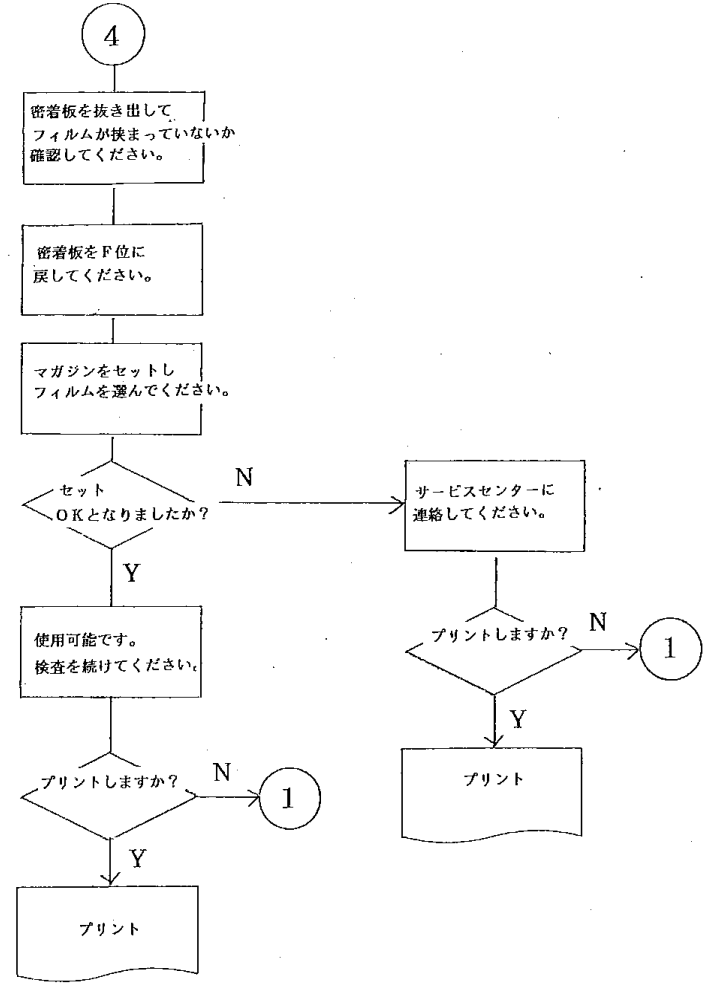

Fig. 8 Flowchart for machine fault analysis program of radiographic/fluoroscopic table---decision point $1-4$

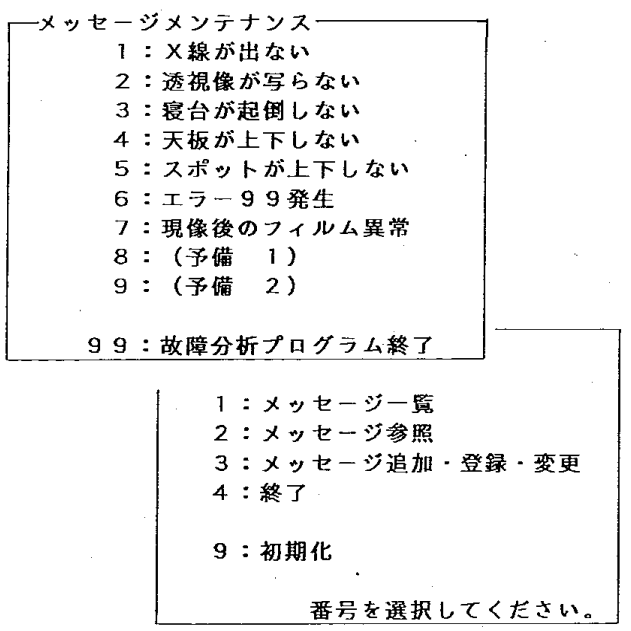

Fig. 9 Display of message maintenance

\section{4. 考察}

現在, X線透視撮影台はほとんどの病院に設置され, 日常業務に使用されている。しかし，故障確率が割合に 少ない装置でもあり，また故障しても複数台の装置を設 置している施設では，他の装置により撮影ができるなど により，故障したときに修理すれば良いという事後保全 の考え方の施設が多い．この傾向は，第46回日本放射線

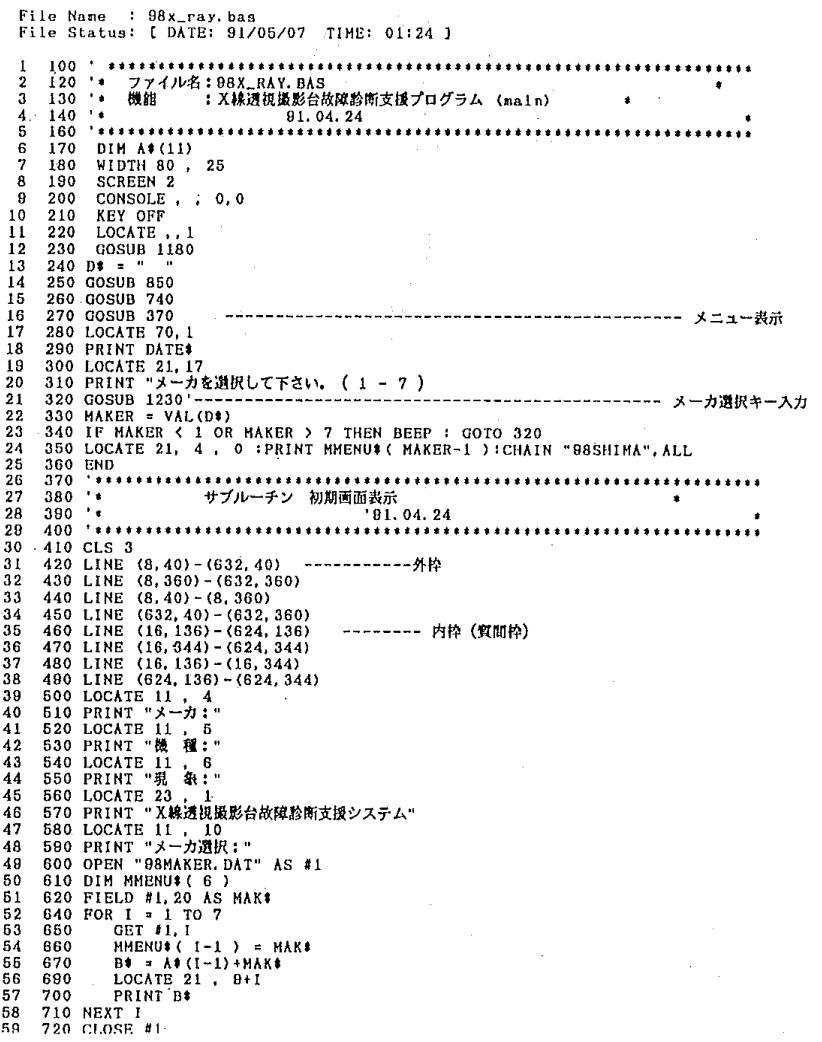

Fig. 10 Machine fault analysis program of Radiographic/Fluoroscopic Table

技術学会総会の公開討論会に打いて発表したように，ア ンケートに回答のあった 227 施設のうち37施設（16.3\%） でしかX線透視撮影台の保守契約の締結がなされていな い現状でも明らかである。（Fig. 11）

また，契約料に納得いけば保守契約したい機種として， 54 施設 $(23.8 \%)$ が透視撮影装置をあげている。約 4 割 の施設が，予防保全の観点とともに，迅速な故障対策を 必要と考えている.

本プログラムを開発していた 2 年の間にも, X線装置 メーカーより新機種が次々と発表されている。 そして最 近の機種はコンピュータ制御が主流で，動作不良時には エラーメッセージあるいはエラーコードが表示されるの で，技師はメッセージに従った対処をするか，エラーコ ードを電話でメーカーに伝えるだけに終わってしまう恐 れもある。自分の施設にあるX線透視撮影台の故障対策 を考えた時, フローチャートで故障分析を行うか，機種 に合わせてプログラム化したパソコンによる故障分析を 行うかで比較しても大差はないと考光るが，フローチャ ートをコンピュータ化することによって得られるメリッ 卜は，新人技師に対する故障対策のシュミレーションと して使用可能で, 予防保全の観点とともに, 迅速な故障 


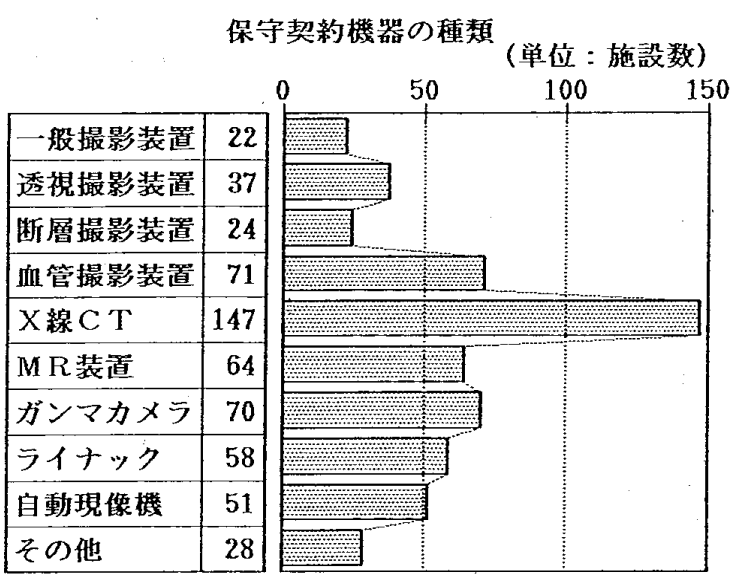

Fig. 11 Classification of maintenance contract

対策が期待できる。

医療機器製造業者の間では, 製品責任予防プログラム と品質保証との連係で各段階ごとにさまざまな名称のも とで安全管理の対策がなされている。製造段階では GMP (Good Manufacturing Practice) により製造品質 を確保している.この段階が $\mathrm{QC}$ 活動にあたり，次の流通 供給段階では GSP（Good Supply Practice）により，製 品技術の情報を使用者に提供し，医療用具の有効性と安 全性を提供する努力がなされている，最後の使用段階で は, 使用者の機器の正しい使用, 機器の保守管理を徹底 することを目的とした GUP（Good Using Practice）が ある5).

最近の IEC の機器の安全教育に関するガイドライン では，単に取り扱い説明書を使用者に提供するだけでな く，ビデオ，スライドなどによる視聴覚教育を使用者側 に行うことを推奖している．事故が生じた場合に GSP が適切であったかを問われるわけで，この故障現象の分 類や故障原因が追及できるプログラムにより，故障好発 部位のチェックが可能となり，機器のダウンタイムの減 少が推定され，使用者の機器の正しい使用，機器の保守 管理を徹底することを目的とした GUP にも発展するも のである。

放射線装置の場合は，その故障を過去に経験したこと があったり，あるいは故障に立ち会った技師の個人的資 礩により，ダウンタイムの時間が異なる傾向にある。し かし, Fig. 9 に示したメッセージメンテナンスの画面よ り，新たに経験した故障現象や，その原因及び対策をブ ロック図に組み込み，メッセージの追加，登録，変更を することにより，その機器に通常起こるとされる故障分 析の対応がマニュアル化される。

かつての自己整流型 $\mathrm{X}$ 線発生装置の時代では，1枚の
回路図でそのすべてを表現することができたし，故障そ の他のトラブルに際しても, 直感的にその故障筒所を推 定し得た。すなわち，機器の操作，および保守点検など を容易に行うことができた6).

しかし，各種医療機器の進歩，開発により今では，直 感的・経験的管理技術のみでは通用しなくなっている. 故障分析枝による解析の手法を用い，パソコンによる故 障現象の分類，故障原因の追及が可能なプログラムを， 放射線機器のメーカーが装置と併せて配布するならば, 製造者と使用者側での GUPにより，より一層の安全管 理，安全使用が徹底されると考える。

\section{5. 結語}

品質管理プログラムの一環として，故障分析枝による 解析の手法を用い，X線透視撮影台の故障分析プログラ ムを開発した．故障現象の分類，故障原因の追及が可能 な本プログラムの利点をまとめると以下のと扔りである.

1.ノート型パソコンを用いることにより，故障現象を 装置のそばでチェックすることができ，現場で修理が可 能か，メーカーの技術者による修理が必要かの対処が速 やかにできる。

2. 過去の故障現象と原因を，プログラム化することに より，装置の故障に立ち会った者が同様に対処できる。

3.メーカーの技術者による修理が必要な場合であって も，予め故障の原因を推定し，故障箇所を亦る程度限定 し，必要な部品を準備するなど，ダウンタイムの減少に つながる。

4. プログラムを活用することにより，故障の好発する 箇所を事前に点恰することにより予防保全が可能となる。 5. 故障発生時を想定したシュミレーションとして, 新 人技師の教育的な効果がある。

稿を終えるにあたり，故障現象の分析と対策でご協力 戴いた東芝メディカル関東サービス琍本田真氏と，故障 分析プログラムを試用しご助言戴いた本田技研和光工場 健康管理センター吉野昇氏に深謝したします。

また，本研究に対しご指導を賜る中平成 3 年 6 月 6 日 急逝された，故高崎克彦国立公衆衛生院放射線衛生学部 医療放射線室長のご冥福をお祈りいたします。

\section{参考文献}

1）放射線管理委員会・機器管理班：医用エックス線装 置設置時のチェック項目ならびに方法。日放技学誌, 41(7), 1161-1178, (1985).

2）日本放射線技術学会専門委員会機器管理班：医用工 
ックス線装置定期点検時のチェック項目ならびに方 法. 日放技学誌，42(7)，1030-1047，(1986).

3）日本放射線技術学会専門委員会放射線技術品質保証 班：品質保証班公開討論会に先立って．日放技学誌， 45 (9)，1589-1592，(1989).

4）諸澄邦彦, 渡辺雅弘, 酒井久恵：オートフィルム千 エンジャーの故障分析プログラムの開発. 日放技学
誌，47(9)，1740，(1991)。

5）日本放射線技術学会専門委員会放射線技術品質保証 班：QA と安全管理. 日放技学誌，46(11)，18351837, (1990).

6）神田幸助：高度医療機器と技術管理一QC, QA の視 点加ら一. 新医療, 17(10), 70-74, (1990). 